Georgia State University

ScholarWorks @ Georgia State University

\title{
$5-2013$
}

\section{Performance Ratings and Career Advancement in the US Federal Civil Service}

Seong Soo Oh

ssoh@pcpp.go.kr

Gregory B. Lewis

Georgia State University, glewis@gsu.edu

Follow this and additional works at: https://scholarworks.gsu.edu/pmap_facpubs

Part of the Public Affairs, Public Policy and Public Administration Commons

\section{Recommended Citation}

Oh, Seong Soo and Lewis, Gregory B., "Performance Ratings and Career Advancement in the US Federal Civil Service" (2013). PMAP Publications. 8.

https://scholarworks.gsu.edu/pmap_facpubs/8

This Article is brought to you for free and open access by the Department of Public Management and Policy at ScholarWorks @ Georgia State University. It has been accepted for inclusion in PMAP Publications by an authorized administrator of ScholarWorks @ Georgia State University. For more information, please contact scholarworks@gsu.edu. 


\title{
PERFORMANCE RATINGS AND CAREER ADVANCEMENT IN THE US FEDERAL CIVIL SERVICE
}

\author{
Seong Soo Oh \\ Department of Public Administration \\ Hanyang University \\ and \\ Gregory B. Lewis \\ Andrew Young School of Policy Studies \\ Georgia State University
}




\title{
PERFORMANCE RATINGS AND CAREER ADVANCEMENT \\ IN THE US FEDERAL CIVIL SERVICE
}

\begin{abstract}
A strong link between performance and rewards in the U.S. federal civil service could raise top performers to positions of power and responsibility and motivate employees to greater productivity. Federal employees, the general population, and scholars all express doubts about the strength of that link, however, though few have estimated it empirically. Using randomeffects panel data models on a one percent sample of federal personnel records for 1988-2003, we examine whether performance ratings meaningfully influence promotion probabilities and annual salary increases. With an average annual promotion rate of 17.8 percent over this period, we estimate that employees with "outstanding" and "less than fully successful" ratings were onefourth more likely and one-fifth less likely, respectively, to receive promotions than those with "fully successful” ratings. Average salary impacts were smaller but still significant. Patterns held up across agencies and stages of the federal careers. Performance ratings continued to affect career advancement one or two years later. We speculate on whether these links are strong enough to motivate performance and advance the most qualified federal employees.
\end{abstract}

Key words: Performance appraisals, pay for performance, salary increase, promotion, federal civil service 


\section{PERFORMANCE RATINGS AND CAREER ADVANCEMENT IN THE US FEDERAL CIVIL SERVICE}

Does the U.S. federal civil service reward good performance? Both scholars and federal employees are skeptical, concerned that rigid civil service rules reward seniority and paper qualifications and make it difficult for managers to raise pay adequately for top performers and to discipline poor performers. A weak link between performance and rewards would create obstacles for both the "best and brightest" and results-oriented public management. The Obama Administration is the latest to propose a government-wide pay-for-performance (PFP) system that "should include large raises for a small group of truly outstanding performers" (Rosenberg 2009; see also Ginsberg 2008, 3), but its implementation is unlikely. Although politically popular, PFP systems have failed repeatedly in the federal service, brought down by inadequate funding and concerns about the quality of performance appraisals.

Current practices in awarding promotions and step increases might already be linking pay to performance more than critics realize, however, though clearly on a smaller scale than PFP systems promise. Some managers find ways around red tape to accomplish other goals: pay has varied by race, sex, and locality despite bureaucratic procedures to block that variation, and pay grade levels have risen over time despite bureaucratic efforts to retain constant definitions of grade levels. Similarly, supervisors may find ways to reward high performers more than we believe.

A better understanding of the impact of performance ratings on career advancement provides a necessary first step for determining whether pay differences between high and low 
performers are large enough to motivate employees. After documenting the skepticism about the performance-reward link in the federal government and the reasons for it and discussing the theoretical desirability of the link and the failed federal efforts to implement pay for performance, we suggest ways that current bureaucratic pay-setting methods may still reward performance. Using a one percent sample of personnel records for federal white-collar employees, we examine whether performance ratings affect promotion probabilities and annual raises.

Our random-effects panel data models control for race, sex, education, federal experience, age, grade level, occupation, supervisory status, and agency. We estimate that employees with "outstanding" ratings were 4.5 and 8.5 percentage points more likely to receive promotions than those with "fully successful" and "less than fully successful" ratings, respectively. On average, outstanding performers received annual raises one-quarter and twothirds percentage point higher than fully successful and less than fully successful performers. The link between ratings and promotions held for almost every agency and stage of the federal career. Ratings continued to affect career advancement one or two years later. We conclude that the links may not be strong enough to yield the expected benefits of a successful pay for performance plan but are stronger than many observers realize.

\section{LITERATURE REVIEW}

\section{Does the Federal Government Link Rewards to Performance?}

Both federal employees and scholars are skeptical that the federal service strongly links rewards to performance. Large surveys of federal employees have long shown that few expect to 
be rewarded for good performance or punished for poor performance (Alonso and Lewis 2001). In the 2005 Merit Principles Survey, for instance, only 31\% expected to receive a cash award or pay increase if they performed well and only $23 \%$ agreed that "Recognition and rewards are based on performance in my work unit" (U.S. Merit Systems Protection Board 2005).

Scholars of public bureaucracies typically reject Herbert Simon's argument $(1991,34)$ that "Everything said here about economic rewards applies equally to privately owned, nonprofit, and government-owned organizations. The opportunity for, and limits on, the use of rewards to motivate activities toward organizational goals are precisely the same in all three kinds of organizations" (quoted in Feeney and Rainey 2010, 804). Instead, Rainey, Backoff, and Levine $(1976,240)$ note a consensus in the literature that "merit principles limit the flexibility of public administrators in hiring, firing, and controlling the incentives of their subordinates." Several surveys find that public sector managers are much more likely than those in the private sector to agree that "formal pay structures and rules make it hard to reward a good manager with higher pay” (Feeney and Rainey 2010, 805). Johnson and Libecap (1989b, 53-4) argue that "federal employees are so protected by civil service rules that their salaries are little affected" by personal or organizational performance. Light (1999) argues the linkage between performance and rewards is so weak that performance appraisals fail to motivate employees to improve their performance.

On the other hand, Johnson and Libecap (1989b, 56) cite Dalton's “iron law of American bureaucratic practice" $(1987,265)$ : "There's always a way to get around the rule." Although the U.S. Office of Personnel Management (OPM) enforces job classification rules intended to ensure equal pay for equal work across individuals, time periods, and (to a lesser extent) geographic 
locations, federal supervisors seem to find ways around those rules. Federal pay varies with race and sex more than can be explained by obvious measures of qualifications (e.g., Lewis and Oh 2009). Federal grade levels (the basis on which salaries are set) have risen faster than the apparent qualifications of federal workers or the demands of their job, partly because the federal pay scale has not risen as rapidly as private sector pay (Lewis 1997a; Johnson and Libecap 1989b). In 1978-80, when federal blue-collar but not white-collar pay was supposed to respond to local market conditions, federal white-collar pay for comparable workers was still higher in areas where private sector pay was higher, apparently because supervisors assigned "employees to higher grade levels than were formally warranted" (Olson, Schwab, and Rau 2000, 272). If federal supervisors want to reward top performers, they may find ways to do so.

\section{Should the Federal Government Link Rewards to Performance?}

Several theories provide the rationale for connecting rewards to performance. According to equity theory, employees' work motivation depends on their perceptions of the balance between their inputs to the organization and their returns from the organization (Adams 1965). Employees consider both internal equity, whether their input is greater or smaller than the rewards, and external equity, whether their outcome-to-input ratio matches those of their coworkers. Equity theory argues that employees try to reach a balance either by reducing their input (work effort) if they are under-compensated or by raising their input if they are overcompensated, either in terms of internal or external equity. Many empirical studies support the theory, particularly on the claim that undercompensated workers lower their input to achieve equity (Heneman and Werner 2005; Ambrose and Kulik 1999; Griffeth, Vecchio, and Logan 1989). Thus, equity theory implies that performance-based rewards will only be effective if 
employees perceive the rewards they receive to be equitable compared to both their input and other employees (Gabris and Ihrke 2000). Meaningful reward differences between high and average performers should help retain high performers and keep their performance levels high, though higher rewards for some than their coworkers believe is warranted by productivity could lower effort by those feeling mistreated.

Expectancy theory (Vroom 1964) argues that, for rewards to motivate employees, workers should perceive that more effort leads to higher performance (expectancy), that improved performance leads to higher rewards (instrumentality), and that the rewards are valuable to them (valence). As instrumentality is a necessary condition for rewards to motivate employees, performance must affect rewards. If performance appraisals accurately reflect performance, higher appraisals must lead to higher rewards. Although critics argue that performance ratings may not accurately reflect performance, PFP, by definition, is an incentive plan that "reward[s] employees based on subjectively rated measures of performance" (Heneman and Werner 2005, 6).

Organizations use performance appraisals for both developmental and judgmental purposes (Boswell and Boudreau 2002; Daley 1992, 2005; Rynes, Gerhart, and Parks 2005). Developmental purposes distinguish within individuals whereas judgmental purposes distinguish among individuals (Cleveland, Murphy, and Williams 1989). Developmental uses focus more on individuals' potential than on current levels of skills and abilities; they include identifying strengths, weaknesses, and training needs of the employees. Judgmental appraisals identify better and worse performers by comparing individuals to one another or to set standards, to enable the organization to make administrative decisions. According to Daley $(1992,17)$, 
"promotion and merit pay are the two most widely known and used of the judgmental appraisal purposes." In practice, judgmental appraisals that affect pay and promotion decisions are more common than developmental appraisals (Murphy and Cleveland 1995; Daley 1992).

Both expectancy and equity theories suggest that motivation increases when better performance leads to higher performance ratings and higher ratings lead to higher rewards, in particular, promotions and pay increases. Mitra et al. (1995) argue that pay must differ meaningfully to motivate employees. They claim that merit salary increases that are too small can decrease employee motivation and that merit pay raises should be at least 6 to 7 percent to be effective. Fuller and Tinkham (2002) argue that, in an effective reward differentiation program, outstanding performers (the top 5 to 15 percent) receive performance pay that is twice that of average performers and poor performers receive 40 percent less than average performers.)

In practice, however, the amounts of performance pay do not seem to vary much among employees in either the private or the public sector (Heneman and Werner 2005; Zenger 1992; Murphy 1992). According to Teel (1986), "most of the organizations surveyed awarded 60 percent or more of their employees raises that varied no more than 2 percent from the average" (p. 90). The cumulative effect can be quite limited even in large companies: employees with the highest performance ratings in two major U.S. corporations had annual salaries only 6 to 8 percent higher than employees with the lowest performance ratings, after controlling for level of education, years of work experience, region, and grade level (Medoff and Abraham 1981). Likewise, the few existing studies of linkages between performance ratings and promotions in the private sector find only moderate effects (Castilla 2008). In his analysis of a large private firm, Mobley $(1982,601)$ found that, out of 100 possible points in its promotion decisions, an 
employee's performance "appraisal contributed 30 percent to promotion rankings, with training, experience, and veteran status also contributing." Lyness and Heilman (2006) analyzed 448 upperlevel managers in a private company and found that as performance rating increased by one level on a three-point scale, the odds of promotion rose 53 percent for female managers and 13 percent for male managers, holding constant age, organizational tenure, education, and organizational level.

\section{Efforts to Link Rewards to Performance in the Federal Government}

The federal government has repeatedly tried to pay based on performance. Under the Performance Management and Recognition System (PMRS) introduced in 1985, employees in grades 13 to 15 who received outstanding ratings were supposed to receive performance awards of 2 to 10 percent of their pay in addition to the general pay increase, whereas those with the bottom two ratings were to receive only 50 percent of the general pay increase or no pay increase at all (Riccucci and Naff 2008). Although PMRS survived for several years despite general dissatisfaction (Perry, Petrakis, and Miller 1989), Congress terminated it in 1993, because performance ratings were suspect and observers doubted that top performance yielded meaningful raises (Nigro and Nigro 2000, 143). In theory, the Senior Executive Service (SES) uses PFP, but only 26 percent of SES members agree that "Pay distinctions are meaningfully different among executives" (U.S. Office of Personnel Management 2008b, 2).

Under George W. Bush, Congress granted the two largest federal departments, the Department of Defense (DOD) and the Department of Homeland Security (DHS), authority to develop their own pay systems. The National Security Personnel System (NSPS) in DOD and the Max-HR in DHS aimed to introduce department-wide pay-for-performance systems (Hyde 
2005). President Bush also tried to introduce such personnel systems to all federal departments and agencies in 2006, but failed to get necessary political support (Eremin, Wolf, and Woodard 2010). Critics charged that performance evaluation in both systems was unfair and inconsistent, and, under Barack Obama, Congress repealed both NSPS and Max-HR in 2009.

Thus, the vast majority of federal civilian employees continue to be paid using traditional federal methods. The General Schedule (GS) is by far the largest federal pay system. GS employees' pay depends almost entirely on their grade and step, with some modifications for difficult-to-fill occupations and high-cost locations. The GS pay system assigns employees to one of 15 grades, based on the difficulty, responsibility, and required qualifications of their positions. Each grade is divided into 10 steps. Congress and the President establish a base salary for each grade-step combination and employees receive that salary, plus locality pay adjustments for 31 metropolitan areas.

Federal employees' pay rises when Congress and the President increase the pay schedule, when they are promoted to a higher grade, or when they move up one or more steps. (Employees may also see their pay rise when they move into metropolitan areas with locality pay adjustments or into particular occupations.) Employees in occupations with job ladders can receive noncompetitive promotions up to the full performance level. Beyond that level and in other occupations, employees compete for promotions. Employees who are not promoted typically receive within-grade (step) increases once a year up to step 4, every other year up to step 7 , and every third year up to step 10 .

Critics argue that the GS rewards seniority rather than performance and that top performers have few opportunities to earn more than average employees (Smith 2012; Zephrine 
and Pantaleo 2010). Performance, however, can affect both promotions and step increases to varying extents. Job-ladder promotions require at least fully successful performance ratings, though almost all employees receive them. Competitive promotions theoretically go to the most qualified applicant, who should disproportionately be earning outstanding ratings. Some federal agencies explicitly state that they base promotion decisions on performance appraisals (U.S. Office of Personnel Management 2008d; National Institute of Standards and Technology 2009). Research on the actual impact of performance ratings on promotions is rare, but the GAO (2003) reported that performance ratings have a "modest" impact on promotion chances of federal workers and Powell and Butterfield (1994) found that performance ratings had a significant effect on promotion decisions into 39 SES positions in one Cabinet level department. Step increases also require satisfactory performance ratings. In addition, some outstanding performers (about 3 percent of GS employees annually) receive "quality step increase," which move them up more rapidly (Olson, Schwab, and Rau 2000, 276).

In sum, scholarly, popular, and employee perceptions of civil service restrictions and bureaucratic inertia suggest that performance has little impact on federal pay. In response to those perceptions, desires to make government function more like business, and scholarly theories of worker motivation, the federal government has repeatedly attempted to implement pay for performance systems, with little success. Nonetheless, we hypothesize that better performance does meaningfully raise pay through its impact on career advancement: federal employees with higher performance ratings should see their pay rise faster than others, because they receive more and faster promotions and step increases. We do not have clear expectations of whether the effect is strong enough to motivate employees, but the null hypothesis of no such 
linkage would indicate that the federal service advances employees without regard to merit and would give employees who desire higher pay little reason to work harder. Even too weak a linkage would suggest that the extrinsic rewards for performance are insufficient to motivate employees.

\section{DATA AND METHODS}

We use a one percent random sample of the Central Personnel Data File (CPDF) for 1988 to 2003. OPM collects personnel data from all but a handful of federal agencies and draws a one percent random sample annually from the CPDF for study purposes. Because employees are selected based on the final three digits of their social security numbers, those in the sample one

year remain in the sample for all years in which they work for the government in April, allowing us to track them over time to identify promotions and measure salary increases. We restrict the sample to full-time, white-collar employees in the General Schedule (GS) and equivalent pay systems.

Our dependent variables are promotion and percentage change in salary. Promotion is a dummy variable coded 1 for employees' whose grades increased in the year after the performance rating. Some employees receive temporary promotions, rising to a higher grade for a year or less, and then dropping back to their prior grade; we eliminate these temporary grade changes from both the promotion and salary change analyses. Annual percentage change is superior to dollar change for measuring salary growth, as our analysis examines both high- and low-salary employees over a 15 -year period. Salaries can increase due to promotions, step 
increases, and statutory increases in the federal pay schedule or locality pay under the Federal Employees’ Pay Comparability Act of 1990 (FEPCA).

Because simple bivariate analyses of the impact of performance ratings on promotion rates and grade/step/salary increases are too misleading, our main analyses are random effects panel data models combining all years of data and controlling for a wide variety of individual and job characteristics. We use logit analysis for promotion chances and regression analysis for salary increases. Random effects panel data models are superior to pooled cross-sectional, time series models, because they recognize that we are following the same individuals over time and correct for the positive autocorrelation of error terms within individuals (Wooldridge 2009, 490). For our purposes, random effects models are superior to fixed effects models, as they allow us to include time-constant variables (like race and sex) and to treat performance ratings both as imperfect measures of underlying ability and effort and as signals to which employees can respond. In fixed effects models, we would only be looking at how over-time variation in employees' performance ratings affects their career advancement in the short run, holding constant any part of their ability that is time-constant. ${ }^{1}$

Our key independent variable is performance rating, which we measure in three ways. First, we treat the five-level measure as interval level, assuming that each one-point rise in rating had the same impact on the log-odds of promotion and on the percentage salary increase. Second, to allow different one-level rises in rating to have different impacts on promotions and salary increases, we substituted three dummy variables -- Outstanding, Exceeds fully successful,

\footnotetext{
${ }^{1}$ Wooldridge $(2009,490)$ notes that the random effects model uses "quasi-demeaned data on each variable. The fixed effects estimator subtracts the time averages from the corresponding variable. The random effects transformation subtracts a portion of that time average." The average of a time-constant variable is constant, of course, so that variable drops from the model. This also applies to omitted variables.
} 
and Less than fully successful. ${ }^{2}$ (Because only 0.4 percent of employees received the two bottom ratings, we combined them into one.) Our reference group is Fully successful, so coefficients represent differences in log-odds of promotion or in percentage salary increase for a person receiving a particular rating and a comparable person receiving a fully successful rating. As we discuss below, the difference between "outstanding" and "exceeds fully successful" ratings is significantly larger than the difference between "exceeds fully successful" and "fully successful" ratings. Consequently, we do not report the results from the "linear" specification for the main analysis.

Third, we allow for the possibility that performance ratings have lingering effects on promotions and salary increases for the following two years. In a second model for each dependent variable, we add six dummy variables for performance ratings in the previous two years. We also include two dummy variables for whether the employee was promoted in the previous two years.

The random effects panel data models include dummy variables for year to allow arbitrary trends in performance ratings and promotions and, most importantly, to capture annual changes in the GS pay schedule under FEPCA. (In unreported models, we also add dummy variables for metropolitan areas to capture the effects of locality pay, but these do not

\footnotetext{
${ }^{2}$ Several federal agencies have moved from five-level rating systems to three-level or pass/fail rating systems since 1996. As both systems are too crude to provide a basis for pay and promotion decisions (Montoya and Graham 2007; Liff 2007), we dropped them from the analysis.Although Liff (2007) writes that the goal of pass/fail system is to "weed out" poor performers, analysis on a one percent sample of CPDF shows that among those who were under pass/fail system only 0.12 percent of federal employees received "fail" ratings and that there is no significant difference in exit rate between those who received "pass" and those who received "fail." Only a few federal employees are under three-level rating system and among those, only a few or no (in some years) employees received the lowest rating. In addition, there is no evidence that the highest rating lead to higher salary increase or higher promotion probabilities than mid-level rating, meaning three-level rating system is not much different from pass/fail system in terms of the use of the results.
} 
meaningfully change the coefficients of interest.) We lose two years of data in Model 2 due to the lags, dropping two year dummy variables from the model.

Our models control for a variety of individual and job characteristics that may influence both performance ratings and career advancement. We measure education, federal experience, and age in years and add squared terms for experience and age to capture their curvilinear impacts on salary growth and promotion probability (salary rises faster, and promotion probabilities drop faster, early than late in one's careers). We create seven dummy variables to distinguish Black males, Hispanic males, Asian males, White females, Black females, Hispanic females, and Asian females from white males, the reference group. (We drop American Indians and "others" from the sample.) Salary rises with grade, but promotion probabilities drop. We create a set of dummy variables for each grade level and for the Senior Executive Service, which is labeled as grade 16 for convenience. Because so few employees are in grades 1 and 2, we combine them into grade 3 . The reference group is grade 8 .

Following the OPM classification, we create dummy variables for Professional, Administrative, Technical, and Clerical occupations with the Other category as the reference group. A dummy variable Supervisory status is coded 1 for supervisors and managers and 0 for everyone else. Because organizational factors strongly affect performance ratings and personnel decisions (Condrey and Brudney 1992) - performance ratings vary dramatically by agency (Lewis 1997b) -- we create dummy variables for all Cabinet-level departments and the four largest independent agencies . All other agencies are combined into the reference group, Other agency. 
Logit analysis assumes that the log-odds of promotion are a linear function of the independent variables. Because the probability of promotion is a nonlinear transformation of the log-odds, the percentage change implied by a logit coefficient depends on the values of all the independent variables. In our main analysis, we use the average partial effect approach to convert logit coefficients into probability differences (Wooldridge 2009, 583; Bartus 2005). We calculate each employee's probability of promotion four times, as if he/she had received each of the four ratings. We then calculate the mean differences in probabilities between comparable employees with different ratings.

Because performance ratings vary so strongly across agencies, the same rating may have different effects in different agencies. Potentially, ratings might only impact promotions and salary increases in a handful of agencies. Likewise, ratings might matter at some points in the career (perhaps in the early years) and not at others. To test whether the impact of performance ratings is robust, we run separate random effects panel data models for each agency as well as separate logit and regression models for employees in each year of service. Because an employee can only be in his/her first year of service once, we do not need panel data models and simply combine years, adding in the dummy variables for year. To simplify the presentation, we use the five-level performance rating variable instead of three dummy variables in these analyses. These models do not include lagged performance ratings and promotions. Based on findings of nearly "linear" relationships between grade and both promotions and salary increases in the main analysis, we also substitute a single grade variable for the set of dummy variables.

\section{FINDINGS}


Simple bivariate analyses (Table 1) suggest that performance ratings have little impact on career success, even that the impact might be perverse. Outstanding performers had slightly lower promotion rates and smaller mean percentage salary increases than those who received fully successful ratings. Indeed, those with unacceptable performance ratings were slightly more likely than outstanding performers to be promoted.

--- --- --- Table 1 about here --- --- ---

These bivariate analyses are misleading, largely because performance ratings rise over the career, while job rewards (measured as year-to-year increases) decline (Table 2). The mean performance rating rises at a decreasing rate over the first dozen years of federal experience (climbing from a mean of 3.56 in first year to 3.98 in the sixth, to 4.09 in the eleventh), then plateaus for the remainder of the career. Despite having relatively low ratings, nearly half of federal employees received promotions between their first and second years, but promotion rates declined at a decreasing rate over the next thirty years as ratings rose. The average first-year employee's salary rose almost 10 percent in the second year, but mean salary increases fell steadily with experience and were only 5 to 6 percent annually (primarily due to changes in the pay schedule) after the first ten years. Average grade increases fell even more rapidly, partly because professional and administrative employees in their first five years of service frequently receive two-grade promotions (from 5 to 7 to 9 to 11 ), whereas more experienced employees (and those in other occupations) typically are promoted only one grade at a time. Further, new employees who do not receive promotions are very likely to receive step increases, which also raise salaries, but step increases become less common as time-in-grade lengthens. 
Most of the control variables influence promotions and salary increases. Table 3 confirms that both probability of promotion and percentage salary increase fall at a decreasing rate with age and federal experience, even holding the other variables constant. They also drop substantially with grade level. Professionals and administrators have higher promotion rates and salary increases than technical, clerical, and other employees at the same grade levels; promotion chances and raises are smallest for clerical workers. Supervisors and managers have higher promotion chances (but not salary increases) than comparable employees at the same grade level in the same occupational category. Promotion chances and salary increases vary substantially across agencies and over the years. Better-educated employees are more likely to be promoted and receive higher salary increases, on average, than less-educated employees in similar positions. Holding all these factors constant, whites, Hispanics, and Asian men have higher promotion chances than blacks and Asian women. The former group also receives higher pay increases, except that Asian men fall from the higher to the lower group.

--- --- --- Table 3 about here --- --- ---

Holding all these variables constant, Model 1 indicates that the odds of promotion for employees with outstanding ratings are 1.5 times as high as those for comparable employees with fully successful ratings. The odds of promotion are 13 percent higher for those with exceeds fully successful ratings than for comparable employees with fully successful ratings, and the odds are only 63 percent as high for employees with less than fully successful as for those with fully successful ratings. The probabilities of promotion vary dramatically based on employees' other characteristics; for employees with outstanding ratings, for instance, probabilities varied between 0.3 and 95.3 percent, with a mean of 17.8 percent. With exceeds 
fully successful, fully successful, and less than fully successful ratings, those mean probabilities would be 14.6, 13.2, and 9.3 percent, respectively. Thus, on average, an outstanding performer's probability of promotion was 4.5 percentage points higher, an exceeds fully successful performer's probability was 1.4 percentage points higher, and a less than fully successful performer's probability was 4.0 percentage points lower than the probability for a fully successful performer with the same characteristics,.

Employees with outstanding ratings got annual raises that were 0.3 percentage point higher, on average, and those with less than fully successful ratings got raises 0.4 percentage point lower, than comparable employees with fully successful ratings. Comparable fully successful and exceeds fully successful employees did not differ significantly in their raises. The 0.7 percentage point difference between the best and worst performers was about one-tenth of the average annual salary increase of 6.9 percent, and the 0.3 point gap between outstanding and average performers was about 5 percent of the average increase.

The effect of performance ratings are cumulative for two reasons. First, although some speculate that supervisors rotate outstanding ratings among their subordinates (Kellough and Nigro 2002; Lawler 2000), individuals' performance ratings are strongly correlated across time: this year's ratings are correlated .66 with ratings one year earlier and .53 with ratings two years earlier. On average, employees who received an outstanding rating in one year have a 78 percent change of receiving another the next year and a 72 percent chance of getting one the following year. Second, Model 2 shows that performance ratings continue to affect promotion chances and raises for at least a second year. Promotions in each of the previous two years had significant positive impacts on both promotions and salary increases in the current year. Because better 
performance ratings in previous years increased one's probability of getting those promotions, these models understate the effects of prior ratings by controlling for those promotions. Even so, last year's performance rating has almost as much impact as this year's rating on career advancement in the next year. Indeed, a less than fully successful rating last year hurts both promotion chances and next year's raise more than a similar rating in the current year. In the salary increase model, an outstanding rating two years ago is still having an impact.

As shown in Table 4, the odds-ratio on rating is greater than 1 in every promotion model by agency and length of federal service; it is significant in 13 of 17 agencies and in every year of service from the second to the twenty-seventh. The effect rises somewhat with experience ratings appear to matter more in late- than early-career promotions. Salary-increase regession coefficients are overwhelmingly positive and usually significant. The mean coefficient is about 0.2 across both agency and experience level, suggesting that outstanding performers' raises average 0.4 percentage point more than fully successful performers. Unlike the promotion oddsratios, however, the salary coefficients do not increase with experience. In sum, ratings affect promotion probabilities and salary increases across agencies and at all stages of the federal career.

\section{--- --- --- Table 4 about here --- --- ---}

\section{CONCLUSIONS}

Linking rewards to performance is a key element for successful performance-based rewards system. Although many observers assume that the relationship between performance and pay is weak in the federal service, only a handful of studies have attempted to empirically estimate the link. We provide the most systematic examination to date on the impact of 
performance ratings on career advancement and pay increases, by performing a panel data analysis of a one percent sample of federal white-collar employees for 1988 through 2003.

We find a consistent positive impact of performance ratings on promotion probabilities. Outstanding performers' odds of promotion are about 50 percent higher than those of fully successful performers, a pattern that appears reasonably consistent across agencies and stages of the federal career. Averaged over the employees in the data set, an outstanding rating raises the probability of promotion by 4.5 percentage points relative to a fully successful rating and by 8.5 points relative to a less than fully successful rating. Employees with outstanding ratings get annual raises about one-quarter to two-thirds percentage point higher, on average, than those with fully successful or less than fully successful ratings. The effects are cumulative: employees typically get about the same ratings from year to year, and performance ratings having an impact over two or three years. Thus, the employees whom supervisors identify as being in the top third are promoted significantly faster and further than average employees.

Is this performance-rewards link strong enough to retain the federal government's best employees, to advance them to the top levels of the bureaucracy, and to motivate workers to improve or maintain their performance? The link is certainly not as strong as recommended by some management scholars who argue that for employees to perceive as "making a difference with regard to their attitudes and behaviors", merit increase should be about 7 percent (Mitra, Gupta, and Jenkins 1997; Heneman and Werner 2005, 142), but the evidence supporting their claim is also weak. The federal link is largely through promotions, which are relatively uncommon, particularly late in the career, rather than through variation in annual merit increases. Federal pay rises primarily through annual increases in the pay schedule and through step 
increases, which occur nearly automatically with seniority. (Few are denied them, and only 3 percent receive quality step increases (Olson, Schwab, and Rau 2000).)

The bureaucratic nature of federal pay also simplifies life for federal supervisors, however, as they have to make fewer pay decisions (Johnson and Libecap 1989a). It may also lower employee concerns about the fairness of supervisor actions and federal pay. Leete (2000), for instance, argues that nonprofit organizations intentionally keep pay differences among employees small to keep them focused on intrinsic rather than extrinsic motivation. As intrinsic motivation is also very important in the federal service (e.g., Perry and Wise 1990) and as extrinsic reward systems appear to motivate intrinsically motivated workers less than the extrinsically motivated (Oh and Lewis 2009), federal motivation may benefit from employees making fewer comparisons about pay increases. Stouffer et al. (1949), for instance, found that during World War II concerns about fairness in promotions hurt morale much more in the Army Air Corps, where promotions were common, than in the military police, where they were rare (cited in Babbie 2007, 12).

Although the overall impact of performance appraisal ratings on career advancement seems to be weak, outstanding ratings clearly give higher chances of promotion to the employees in the federal civil service. In other words, despite claims that rating inflation in federal performance appraisals has made them useless (Light 1999), they still have significant impacts on personnel decisions. Thus, the strong trend from traditional five level ratings to pass or fail systems (half of federal agencies have made the change; Henry 2009) is troubling, as the absence of distinctions between outstanding, above-average, and average performance makes the passfail system an ineffective tool to serve personnel decisions (Liff 2007; Montoya and Graham 
2007). Instead of giving up an important judgmental purpose of performance appraisals, federal agencies need to improve their performance appraisal systems to become a helpful tool to make personnel decisions. Within the structure of the General Schedule, the government might also work to build a stronger link between performance and rewards by changing the process for awarding step increases. Managers could potentially allow step increases only for those who earn ratings that exceed fully successful and make more use of quality step increases. Such a change, however, could increase pressure on supervisors to inflate ratings, escalate charges of favoritism in ratings, and hurt employee morale.

By providing empirical evidence on the impact of performance ratings on personnel decisions, this study expands our understanding of performance-based rewards in the federal civil service. Because OPM only released data through 2003, however, we could not assess how performance appraisals affected pay raises under NSPS and Max-HR. Future research should examine how explicit pay-for-performance systems affected the distribution of rewards in the Departments of Defense and Homeland Security. 


\section{REFERENCES}

Adams, J. S. 1965. "Inequity in Social Exchange." In Advances in Experimental Social Psychology, edited by L. Berkowitz. New York: Academic Press.

Alonso, Pablo, and Gregory B. Lewis. 2001. "Public Service Motivation and Job Performance: Evidence from the Federal Sector." The American Review of Public Administration no. 31 (4):363-380.

Ambrose, Maureen L., and Carol T. Kulik. 1999. "Old Friends, New Faces: Motivation Research in the 1990s." Journal of Management no. 25 (3):231-292.

Babbie, Earl. 2007. The Practice of Social Research. 11th ed. Belmont, CA: Thompson Wadsworth

Bartus, Tamas. 2005. "Estimation of Marginal Effects Using margeff." Stata Journal no. 5 (3):309-329.

Boswell, W. R., and J. W. Boudreau. 2002. "Separating the developmental and evaluative performance appraisal uses." Journal of Business and Psychology no. 16 (3):391-412.

Castilla, Emilio J. 2008. "Gender, Race, and Meritocracy in Organizational Careers." American Journal of Sociology no. 113 (6):1479-1526.

Cleveland, J. N., K. R. Murphy, and R. E. Williams. 1989. "Multiple uses of performance appraisal: Prevalence and correlates." Journal of applied psychology no. 74 (1):130-135.

Condrey, Stephen E., and Jeffrey L. Brudney. 1992. "Performance-Based Managerial Pay in the Federal Government: Does Agency Matter?" Journal of Public Administration Research and Theory no. 2 (2):157-174.

Daley, Dennis M. 1992. Performance Appraisal in the Public Sector: Techniques and Applications. Westport, CT: Quorum Books.

— 2005. "Designing Effective Performance Appraisal Systems." In Handbook Of Human Resource Management In Government, edited by Stephen E. Condrey. San Francisco: Jossey-Bass.

Dalton, Melville. 1987. Men Who Manage. New York: John Wiley.

Eremin, D.V., J.F. Wolf, and C.A. Woodard. 2010. "Systemic Bias in Federal Performance Evaluations." Public Performance \& Management Review no. 34 (1):7-21.

Feeney, Mary K., and Hal G. Rainey. 2010. "Personnel Flexibility and Red Tape in Public and Nonprofit Organizations: Distinctions due to Institutional and Political Accountability." Journal of Public Administration Research and Theory no. 20 (4):801-26.

Fuller, Jeffrey J., and Rebecca Tinkham. 2002. "Making the Most of Scarce Reward Dollars: Why Differentiation Makes a Difference." Employee Benefits Journal no. 27 (3):3-8.

Gabris, G. T., and D. M. Ihrke. 2000. "Improving Employee Acceptance toward Performance Appraisal and Merit Pay System: The Role of Leadership Credibility." Review of Public Personnel Administration no. 20 (1):41-53.

Ginsberg, Wendy. 2008. Pay for Performance: The National Security Personnel System. Washington, DC: Congressional Research Service.

Griffeth, R. W., R. P. Vecchio, and J. W. Logan. 1989. "Equity theory and interpersonal attraction." Journal of applied psychology no. 74 (3):394-401.

Heneman, Robert L., and Jon M Werner. 2005. Merit Pay: Linking Pay to Performance in a Changing World. Greenwich, CT: Information Age Publishing. 
Henry, Nicholas. 2009. Public Administration and Public Affairs. New York: Pearson. Hyde, Albert C. . 2005. "Pay for Performance." Public Manager no. 34 (1):3-7.

Johnson, Ronald N., and Gary D. Libecap. 1989a. "Bureaucratic Rules, Supervisor Behavior, and the Effect on Salaries in the Federal Government " Journal of Law, Economics, \& Organization no. 5 (1):53-82.

- 1989b. "Bureaucratic Rules, Supervisor Behavior, and the Effect on Salaries in the Federal Government." Journal of Law, Economics, and Organization no. 5 (1):53-82.

Kellough, J. Edward, and Lloyd G. Nigro. 2002. "Pay for Performance in Georgia State Government: Employee Perspectives on GeorgiaGain After 5 Years." Review of Public Personnel Administration no. 22 (2):146-166.

Lawler, E. E. 2000. Rewarding Excellence, Pay Strategies for the New Economy,

. San Francisco, CA: Jossey-Bass.

Leete, Laura. 2000. "Wage Equity and Employee Motivation in Nonprofit and For-profit Organizations." Journal of Economic Behavior \& Organization no. 43 (4):423-446.

Lewis, Gregory B. 1997a. "Grade Creep in the Federal Service?" The American Review of Public Administration no. 27 (1):4-21.

Lewis, Gregory B. . 1997b. "Race, Sex, and Performance Ratings in the Federal Service." Public Administration Review no. 57 (6):479-489.

Lewis, Gregory B., and Seong Soo Oh. 2009. "A Major Difference?: Fields of Study and MaleFemale Pay Differences in Federal Employment." The American Review of Public Administration no. 39 (2):107-124.

Liff, Stewart. 2007. Managing Government Employees: How to Motivate Your People, Deal With Difficult Issues, And Achieve Tangible Results. New York: American Management Association.

Light, Paul C. 1999. Behold Lake Wobegon East. Government Executive.

Lyness, Karen S., and Madeline E. Heilman. 2006. "When Fit Is Fundamental: Performance Evaluations and Promotions of Upper-Level Female and Male Managers." Journal of Applied Psychology no. 91 (4):777-785.

Medoff, James L., and Katharine G. Abraham. 1981. Experience, Performance, and Earnings. NBER Working Paper No. W0278.

Mitra, A., N. Gupta, and G.D. Jenkins. 1997. "A drop in the bucket: when is a pay raise a pay raise?" Journal of Organizational Behavior no. 18 (2):117-137.

Mitra, Atul, Nina Gupta, and G. Douglas Jenkins. 1995. "The Case of the Invisible Merit Raise: How People See Their Pay Raises." Compensation \& Benefits Review no. 27 (3):71-76.

Mobley, William H. 1982. "Supervisor and Employee Race and Sex Effects on Performance Appraisals: A Field Study of Adverse Impact and Generalizability." Academy of Management Journal no. 25 (3):598-606.

Montoya, Silvia, and John Graham. 2007. Modernizing the Federal Government: Paying for Performance. Santa Monica: RAND Corporation.

Murphy, Kevin J. 1992. "Performance Measurement and Appraisal: Motivating Managers to Identify and Reward Performance." In Performance Measurement, Evaluation, and Incentives, edited by William J. Burns Jr., 37-62. Boston: Harvard Business School Press.

Murphy, Kevin R., and Jeanette N. Cleveland. 1995. Understanding Performance Appraisal: Social, Organizational, and Goal-Based Perspectives. Thousand Oaks: Sage. 
National Institute of Standards and Technology. 2009. Human Resource Systems: Performance Management 2009 [cited February 15 2009]. Available from http://www.nist.gov/hrmd/projectops/hrsystems/performance.htm.

Nigro, Felix A., and Lloyd G. Nigro. 2000. The New Public Personnel Administration, 5th edition. Itasca, IL: FE Peacock Publishers.

Oh, Seong Soo, and Gregory B. Lewis. 2009. "Can Performance Appraisal Systems Inspire Intrinsically Motivated Employees?" Review of Public Personnel Administration no. 29 (2):158-167.

Olson, Craig A., Donald P. Schwab, and Barbara L. Rau. 2000. "The Effects of Local Market Conditions on Two Pay-Setting Systems in the Federal Sector." Industrial and Labor Relations Review no. 53 (2):272-289.

Perry, James L., Beth Ann Petrakis, and Theodore K. Miller. 1989. "Federal Merit Pay, Round II: An Analysis of the Performance Management and Recognition System." Public Administration Review no. 49 (1):29-37.

Perry, James L., and Lois Recascino Wise. 1990. "The Motivational Bases of Public Service." Public Administration Review no. 50 (3):367-373.

Powell, Gary N., and D. Anthony Butterfield. 1994. "Investigating the "glass ceiling" phenomenon: An empirical study of actual promotions to top management." Academy of Management Journal no. 37 (1):68-86.

Rainey, Hal G., Robert W. Backoff, and Charles H. Levine. 1976. "Comparing Public and Private Organizations." Public Administration Review no. 36 (2):233-244.

Riccucci, Norma M., and Katherine C. Naff. 2008. Personnel Management in Government Politics and Process. Boca Raton, FL: CRC Press.

Rosenberg, Alyssa. 2009. Administration will push for governmentwide pay for performance. Government Executive.

Rynes, Sara L., Barry Gerhart, and Laura Parks. 2005. "Personnel Psychology: Performance Evaluation and Pay for Performance." Annual Review of Psychology no. 56:571-600

Simon, Herbert A. 1991. "Organizations and Markets." The Journal of Economic Perspectives no. 5 (2):25-44.

Smith, Jerry O. 2012. The Failure and Replacement of the NSPS 2012 [cited June 4 2012]. Available from http://ezinearticles.com/.

Stouffer, Samuel A., Arthur A. Lumsdaine, Marion Harper Lumsdaine, Robin M. Williams Jr, M. Brewster Smith, Irving L. Janis, Shirley A. Star, and Leonard S. Cottrell Jr. 1949. The American Soldier: Combat and its Aftermath. 3 vols. Vol. 2, Studies in Social Psychology in World War II. Princeton: Princeton University Press.

Teel, Kenneth S. 1986. "Are Merit Raises Really Based on Merit?" Personnel Journal no. 65 (3):88-94.

U.S. General Accounting Office. 2003. Results-Oriented Cultures: Modern Performance Management Systems Are Needed to Effectively Support Pay for Performance. Washington, D.C.: U.S. General Accounting Office.

U.S. Merit Systems Protection Board. 2005. Merit Principles Survey (N=36,926).

U.S. Office of Personnel Management. 2008b. Senior Executive Service Survey Results. Washington, D.C.: U.S. Office of Personnel Management. 
- Performance Management and Quality Step Increases FAQs 2008d. Available from http://www.opm.gov/perform/faqs/qualsi.asp.

Wooldridge, Jeffrey M. 2009. Introductory Econometrics: A Modern Approach. 4 ed. Mason, $\mathrm{OH}$ : South Western Cengage Learning.

Zenger, Todd R. 1992. "Why Do Employers Only Reward Extreme Performance? Examining the Relationships among Performance, Pay, and Turnover." Administrative Science Quarterly no. 37 (2):198-219.

Zephrine, Andre, and M. Pantaleo. 2012. A Study Of The Causes Of The Failure Of The National Security Personnel System 2010 [cited June 4 2012]. Available from http://www.oppapers.com/essays/. 
Table 1. Career Advancement by Performance Rating

\begin{tabular}{|c|c|c|c|c|c|}
\hline $\begin{array}{l}\text { Performance } \\
\text { Rating }\end{array}$ & $\begin{array}{c}\text { Percent } \\
\text { Promoted } \\
\end{array}$ & $\begin{array}{c}\text { Mean Percent } \\
\text { Salary Increase }\end{array}$ & $\begin{array}{c}\text { Mean Grade } \\
\text { Increase }\end{array}$ & $\begin{array}{c}\text { Mean Step } \\
\text { Increase }\end{array}$ & $\begin{array}{c}\text { Sample } \\
\text { Size }\end{array}$ \\
\hline 1 Unacceptable & 16.0 & 5.6 & 0.12 & 0.42 & 125 \\
\hline $\begin{array}{l}2 \text { Less than fully } \\
\text { successful }\end{array}$ & 9.4 & 5.5 & 0.09 & 0.45 & 360 \\
\hline 3 Fully successful & 16.4 & 6.3 & 0.21 & 0.55 & 33,383 \\
\hline $\begin{array}{l}4 \text { Exceeds fully } \\
\text { successful }\end{array}$ & 15.1 & 6.1 & 0.19 & 0.55 & 45,989 \\
\hline 5 Outstanding & 15.4 & 6.1 & 0.19 & 0.55 & 40,761 \\
\hline
\end{tabular}


Table 2. Mean Rating and Career Advancement by Length of Federal Service

\begin{tabular}{cccccc}
$\begin{array}{c}\text { Years of Federal } \\
\text { Experience }\end{array}$ & $\begin{array}{c}\text { Mean } \\
\text { Rating }\end{array}$ & $\begin{array}{c}\text { Percent } \\
\text { Promoted }\end{array}$ & $\begin{array}{c}\text { Mean Percent } \\
\text { Salary Increase }\end{array}$ & $\begin{array}{c}\text { Mean Grade } \\
\text { Increase }\end{array}$ & $\begin{array}{c}\text { Mean Step } \\
\text { Increase }\end{array}$ \\
\cline { 2 - 3 } 2 & 3.56 & 48.1 & 9.8 & 0.77 & 1.02 \\
3 & 3.69 & 43.7 & 9.0 & 0.64 & 0.97 \\
4 & 3.84 & 34.4 & 8.6 & 0.44 & 0.91 \\
5 & 3.91 & 27.4 & 7.7 & 0.35 & 0.83 \\
6 & 3.95 & 23.8 & 7.4 & 0.29 & 0.78 \\
7 & 3.98 & 20.0 & 6.9 & 0.25 & 0.71 \\
8 & 4.00 & 17.9 & 6.7 & 0.22 & 0.67 \\
9 & 4.03 & 17.2 & 6.6 & 0.21 & 0.64 \\
10 & 4.06 & 17.4 & 6.5 & 0.22 & 0.62 \\
11 & 4.07 & 15.4 & 6.4 & 0.19 & 0.60 \\
12 & 4.09 & 14.1 & 6.2 & 0.17 & 0.57 \\
13 & 4.09 & 13.7 & 6.1 & 0.16 & 0.56 \\
14 & 4.10 & 13.9 & 6.1 & 0.17 & 0.54 \\
15 & 4.11 & 12.8 & 5.9 & 0.15 & 0.51 \\
16 & 4.12 & 12.3 & 5.7 & 0.15 & 0.49 \\
17 & 4.11 & 12.5 & 5.8 & 0.14 & 0.50 \\
18 & 4.11 & 12.0 & 5.8 & 0.14 & 0.49 \\
19 & 4.10 & 10.3 & 5.5 & 0.12 & 0.44 \\
20 & 4.11 & 11.5 & 5.6 & 0.14 & 0.45 \\
21 & 4.11 & 10.6 & 5.5 & 0.13 & 0.43 \\
22 & 4.10 & 9.8 & 5.4 & 0.11 & 0.41 \\
23 & 4.11 & 9.2 & 5.3 & 0.10 & 0.39 \\
24 & 4.12 & 9.3 & 5.3 & 0.11 & 0.39 \\
25 & 4.10 & 8.9 & 5.2 & 0.10 & 0.35 \\
26 & 4.11 & 8.1 & 5.1 & 0.09 & 0.36 \\
27 & 4.12 & 8.2 & 5.0 & 0.09 & 0.33 \\
28 & 4.13 & 7.7 & 5.0 & 0.09 & 0.33 \\
29 & 4.10 & 7.3 & 4.8 & 0.08 & 0.30 \\
& 4.10 & 6.6 & 4.8 & 0.07 & \\
& & & & &
\end{tabular}




\section{Table 3. Random-Effects Panel Data Models \\ for Promotion and Salary Increases}

\begin{tabular}{|c|c|c|c|c|}
\hline & \multicolumn{2}{|c|}{ Promotion } & \multicolumn{2}{|c|}{ Salary Increase } \\
\hline & Model 1 & Model 2 & Model 1 & Model 2 \\
\hline \multirow[t]{2}{*}{ Outstanding rating } & $0.405 * * *$ & $0.360 * * *$ & $0.275 * * *$ & $0.356 * * *$ \\
\hline & $(0.0258)$ & $(0.0400)$ & $(0.0405)$ & $(0.0486)$ \\
\hline \multirow[t]{2}{*}{ Exceeds fully successful } & $0.131 * * *$ & $0.141 * * *$ & 0.0381 & $0.209 * * *$ \\
\hline & $(0.0233)$ & $(0.0346)$ & $(0.0352)$ & $(0.0412)$ \\
\hline \multirow[t]{2}{*}{ Less than fully successful } & $-0.462 * * *$ & -0.0674 & $-0.417 * *$ & 0.229 \\
\hline & $(0.161)$ & $(0.212)$ & $(0.210)$ & $(0.236)$ \\
\hline \multirow[t]{2}{*}{ Promoted, previous year } & & $0.372 * * *$ & & $0.617 * * *$ \\
\hline & & $(0.0312)$ & & $(0.0398)$ \\
\hline \multirow[t]{2}{*}{ Outstanding rating, previous year } & & $0.201 * * *$ & & $0.193 * * *$ \\
\hline & & $(0.0444)$ & & $(0.0530)$ \\
\hline \multirow{2}{*}{$\begin{array}{l}\text { Exceeds fully successful, } \\
\text { previous year }\end{array}$} & & $0.117 * * *$ & & $0.0912 * *$ \\
\hline & & $(0.0365)$ & & $(0.0431)$ \\
\hline \multirow{2}{*}{$\begin{array}{l}\text { Less than fully successful, } \\
\text { previous year }\end{array}$} & & $-0.593 * *$ & & $-0.478 * *$ \\
\hline & & $(0.248)$ & & $(0.237)$ \\
\hline \multirow[t]{2}{*}{ Promoted, two years previously } & & $0.102 * * *$ & & $0.939 * * *$ \\
\hline & & $(0.0302)$ & & $(0.0379)$ \\
\hline \multirow{2}{*}{$\begin{array}{l}\text { Outstanding rating, } \\
\text { two years previously }\end{array}$} & & 0.0620 & & $0.116 * *$ \\
\hline & & $(0.0395)$ & & $(0.0483)$ \\
\hline \multirow{2}{*}{$\begin{array}{l}\text { Exceeds fully successful, } \\
\text { two years previously }\end{array}$} & & 0.00804 & & 0.0299 \\
\hline & & $(0.0326)$ & & $(0.0395)$ \\
\hline \multirow{2}{*}{$\begin{array}{l}\text { Less than fully successful, } \\
\text { two years previously }\end{array}$} & & -0.112 & & 0.0739 \\
\hline & & $(0.197)$ & & $(0.220)$ \\
\hline \multirow[t]{2}{*}{ black male } & $-0.0942 * *$ & -0.00368 & $-0.239 * *$ & 0.0342 \\
\hline & $(0.0476)$ & $(0.0542)$ & $(0.103)$ & $(0.0864)$ \\
\hline \multirow[t]{2}{*}{ hispanic male } & 0.0296 & 0.0291 & -0.103 & -0.0557 \\
\hline & $(0.0667)$ & $(0.0783)$ & $(0.147)$ & $(0.123)$ \\
\hline \multirow[t]{2}{*}{ asian male } & -0.0358 & 0.0362 & $-0.366 * *$ & $-0.368 * *$ \\
\hline & $(0.0856)$ & $(0.102)$ & $(0.179)$ & $(0.151)$ \\
\hline \multirow[t]{2}{*}{ white female } & 0.0366 & $0.0714 * *$ & -0.0632 & $0.160 * * *$ \\
\hline & $(0.0270)$ & $(0.0309)$ & $(0.0587)$ & $(0.0497)$ \\
\hline \multirow[t]{2}{*}{ black female } & $-0.145^{* * *}$ & -0.0183 & $-0.492 * * *$ & 0.0588 \\
\hline & $(0.0364)$ & $(0.0404)$ & $(0.0815)$ & $(0.0681)$ \\
\hline \multirow[t]{2}{*}{ hispanic female } & -0.00938 & 0.0463 & -0.174 & 0.164 \\
\hline & $(0.0653)$ & $(0.0719)$ & $(0.155)$ & $(0.130)$ \\
\hline \multirow[t]{2}{*}{ asian female } & $-0.192 * *$ & -0.115 & $-0.489 * * *$ & $-0.366 * *$ \\
\hline & $(0.0794)$ & $(0.0902)$ & $(0.182)$ & $(0.151)$ \\
\hline \multirow{2}{*}{ years of education } & $0.0836 * * *$ & $0.0563 * * *$ & $0.208 * * *$ & $0.0596 * * *$ \\
\hline & $(0.00679)$ & $(0.00771)$ & $(0.0134)$ & $(0.0118)$ \\
\hline
\end{tabular}




\begin{tabular}{|c|c|c|c|c|}
\hline \multirow{3}{*}{$\begin{array}{l}\text { years of federal service } \\
\text { years of federal service squared }\end{array}$} & $\begin{array}{l}-0.116 * * * \\
(0.00552)\end{array}$ & $\begin{array}{l}-0.0542 * * * \\
(0.00829)\end{array}$ & $\begin{array}{l}-0.461 * * * \\
(0.00965)\end{array}$ & $\begin{array}{l}-0.219 * * * \\
(0.0114)\end{array}$ \\
\hline & $0.00321 * * *$ & $0.00134 * * *$ & $0.0122 * * *$ & $0.00472 * * *$ \\
\hline & $(0.000183)$ & $(0.000257)$ & $(0.000293)$ & $(0.000335)$ \\
\hline \multirow{2}{*}{ years of age } & $-0.0363 * * *$ & $-0.0386 * * *$ & $-0.260 * * *$ & $-0.152 * * *$ \\
\hline & $(0.00843)$ & $(0.0110)$ & $(0.0155)$ & $(0.0161)$ \\
\hline \multirow{2}{*}{ years of age squared } & -0.0001 & 0.0000 & $0.00201 * * *$ & $0.00112 * * *$ \\
\hline & $(0.0001)$ & $(0.0001)$ & $(0.000169)$ & $(0.000172)$ \\
\hline \multirow[t]{2}{*}{ supervisor/manager } & $0.106 * * *$ & $0.119 * * *$ & 0.0722 & $-0.139 * *$ \\
\hline & $(0.0366)$ & $(0.0413)$ & $(0.0577)$ & $(0.0553)$ \\
\hline \multirow[t]{2}{*}{ GS-3 } & $1.634 * * *$ & $1.104 * * *$ & $2.827 * * *$ & $1.534 * * *$ \\
\hline & $(0.0994)$ & $(0.143)$ & $(0.188)$ & $(0.225)$ \\
\hline \multirow[t]{2}{*}{ GS-4 } & $1.115^{* * *}$ & $0.921 * * *$ & $1.691 * * *$ & $1.084 * * *$ \\
\hline & $(0.0714)$ & $(0.0843)$ & $(0.124)$ & $(0.126)$ \\
\hline \multirow[t]{2}{*}{ GS-5 } & $0.797 * * *$ & $0.693 * * *$ & $1.467 * * *$ & $0.834 * * *$ \\
\hline & $(0.0628)$ & $(0.0716)$ & $(0.107)$ & $(0.105)$ \\
\hline \multirow[t]{2}{*}{ GS-6 } & $0.759 * * *$ & $0.620 * * *$ & $1.205^{* * *}$ & $0.692 * * *$ \\
\hline & $(0.0610)$ & $(0.0690)$ & $(0.104)$ & $(0.101)$ \\
\hline \multirow[t]{2}{*}{ GS-7 } & $0.385 * * *$ & $0.308 * * *$ & $1.257 * * *$ & $0.577 * * *$ \\
\hline & $(0.0569)$ & $(0.0645)$ & $(0.0946)$ & $(0.0931)$ \\
\hline \multirow[t]{2}{*}{ GS-9 } & $-0.299 * * *$ & $-0.214 * * *$ & $-0.235 * *$ & $0.297 * * *$ \\
\hline & $(0.0608)$ & (0.0699) & $(0.101)$ & $(0.0996)$ \\
\hline \multirow[t]{2}{*}{ GS-10 } & $-0.719 * * *$ & $-0.302 * * *$ & $-1.627 * * *$ & $-0.332 * *$ \\
\hline & $(0.0890)$ & $(0.0971)$ & $(0.150)$ & $(0.146)$ \\
\hline \multirow[t]{2}{*}{ GS-11 } & $-1.149 * * *$ & $-0.864 * * *$ & $-2.156 * * *$ & $-0.620 * * *$ \\
\hline & $(0.0639)$ & $(0.0734)$ & $(0.107)$ & $(0.104)$ \\
\hline \multirow[t]{2}{*}{ GS-12 } & $-2.031 * * *$ & $-1.609 * * *$ & $-3.973 * * *$ & $-1.652 * * *$ \\
\hline & $(0.0682)$ & $(0.0783)$ & (0.110) & (0.108) \\
\hline \multirow[t]{2}{*}{ GS-13 } & $-2.655 * * *$ & $-2.224 * * *$ & $-4.868 * * *$ & $-2.302 * * *$ \\
\hline & $(0.0804)$ & $(0.0931)$ & $(0.123)$ & (0.119) \\
\hline \multirow[t]{2}{*}{ GS-14 } & $-3.118 * * *$ & $-2.484 * * *$ & $-5.946 * * *$ & $-2.727 * * *$ \\
\hline & $(0.105)$ & $(0.121)$ & $(0.149)$ & $(0.143)$ \\
\hline \multirow[t]{2}{*}{ GS-15 } & $-4.312 * * *$ & $-4.146 * * *$ & $-6.080 * * *$ & $-2.846^{* * *}$ \\
\hline & $(0.257)$ & $(0.393)$ & $(0.224)$ & $(0.223)$ \\
\hline \multirow[t]{2}{*}{ prof } & $1.551 * * *$ & $1.078 * * *$ & $3.378 * * *$ & $1.837 * * *$ \\
\hline & $(0.0726)$ & $(0.0859)$ & $(0.148)$ & $(0.136)$ \\
\hline \multirow[t]{2}{*}{ admin } & $1.511 * * *$ & $1.120 * * *$ & $3.591 * * *$ & $2.124 * * *$ \\
\hline & $(0.0669)$ & $(0.0796)$ & $(0.138)$ & $(0.128)$ \\
\hline \multirow[t]{2}{*}{ tech } & $0.157 * * *$ & 0.0198 & 0.0519 & 0.0952 \\
\hline & $(0.0606)$ & $(0.0711)$ & $(0.131)$ & $(0.118)$ \\
\hline \multirow[t]{2}{*}{ cler } & $-0.323 * * *$ & $-0.351 * * *$ & $-1.051 * * *$ & $-0.602 * * *$ \\
\hline & $(0.0647)$ & $(0.0775)$ & $(0.138)$ & $(0.128)$ \\
\hline \multirow[t]{2}{*}{ Air Force } & $-0.638 * * *$ & $-0.524 * * *$ & $-1.308 * * *$ & $-0.730 * * *$ \\
\hline & $(0.0613)$ & $(0.0706)$ & $(0.121)$ & $(0.106)$ \\
\hline
\end{tabular}




\begin{tabular}{|c|c|c|c|c|}
\hline Agriculture & $\begin{array}{l}-0.480 * * * \\
(0.0649)\end{array}$ & $\begin{array}{l}-0.197 * * * \\
(0.0723)\end{array}$ & $\begin{array}{l}-1.020 * * * \\
(0.133)\end{array}$ & $\begin{array}{l}-0.352 * * * \\
(0.113)\end{array}$ \\
\hline \multirow[t]{2}{*}{ Army } & $-0.697 * * *$ & $-0.575 * * *$ & $-1.178 * * *$ & $-0.698 * * *$ \\
\hline & $(0.0579)$ & $(0.0664)$ & $(0.114)$ & $(0.0996)$ \\
\hline \multirow[t]{2}{*}{ Commerce } & $0.392 * * *$ & $0.445 * * *$ & $1.009 * * *$ & $0.968 * * *$ \\
\hline & $(0.0893)$ & $(0.101)$ & $(0.197)$ & $(0.173)$ \\
\hline \multirow[t]{2}{*}{ Defense } & $-0.483 * * *$ & $-0.407 * * *$ & $-0.713 * * *$ & $-0.415 * * *$ \\
\hline & $(0.0660)$ & $(0.0759)$ & $(0.128)$ & $(0.113)$ \\
\hline \multirow[t]{2}{*}{ Justice } & -0.0199 & -0.0431 & 0.0700 & 0.0539 \\
\hline & $(0.0665)$ & $(0.0761)$ & $(0.140)$ & $(0.122)$ \\
\hline \multirow[t]{2}{*}{ Labor } & -0.0426 & 0.0105 & 0.149 & 0.121 \\
\hline & $(0.114)$ & $(0.130)$ & $(0.244)$ & $(0.206)$ \\
\hline \multirow[t]{2}{*}{ Energy } & $0.467 * * *$ & $0.614 * * *$ & 0.309 & $0.681 * * *$ \\
\hline & $(0.109)$ & $(0.119)$ & $(0.233)$ & $(0.198)$ \\
\hline \multirow[t]{2}{*}{ Education } & $0.615 * * *$ & $0.586 * * *$ & $1.348 * * *$ & $0.651 *$ \\
\hline & $(0.182)$ & $(0.212)$ & $(0.414)$ & $(0.362)$ \\
\hline \multirow[t]{2}{*}{ EPA } & $0.393 * * *$ & $0.450 * * *$ & $0.529 * *$ & $0.560 * *$ \\
\hline & $(0.115)$ & $(0.146)$ & $(0.249)$ & $(0.234)$ \\
\hline \multirow[t]{2}{*}{ GSA } & 0.119 & $0.275^{* *}$ & 0.152 & $0.423^{* *}$ \\
\hline & $(0.111)$ & $(0.122)$ & $(0.251)$ & $(0.214)$ \\
\hline \multirow[t]{2}{*}{ HHS } & 0.0489 & $0.356 * * *$ & $-0.393 * * *$ & 0.124 \\
\hline & $(0.0623)$ & $(0.0709)$ & $(0.111)$ & $(0.104)$ \\
\hline \multirow[t]{2}{*}{ HUD } & $0.316 * * *$ & $0.406 * * *$ & $0.552 * *$ & $0.551 * * *$ \\
\hline & $(0.107)$ & $(0.113)$ & $(0.243)$ & $(0.199)$ \\
\hline \multirow[t]{2}{*}{ Interior } & $-0.313 * * *$ & -0.0654 & $-0.768 * * *$ & -0.195 \\
\hline & $(0.0801)$ & $(0.0908)$ & $(0.164)$ & $(0.142)$ \\
\hline \multirow[t]{2}{*}{ NASA } & $0.220 * *$ & $0.336 * * *$ & -0.323 & 0.111 \\
\hline & $(0.106)$ & $(0.120)$ & $(0.225)$ & $(0.191)$ \\
\hline Navy & $-0.439 * * *$ & $-0.377 * * *$ & $-0.800 * * *$ & $-0.575 * * *$ \\
\hline
\end{tabular}




\begin{tabular}{|c|c|c|c|c|}
\hline & $(0.0589)$ & $(0.0672)$ & $(0.117)$ & $(0.101)$ \\
\hline \multirow[t]{2}{*}{ State } & 0.220 & 0.122 & 0.563 & 0.554 \\
\hline & $(0.184)$ & $(0.209)$ & $(0.421)$ & $(0.366)$ \\
\hline \multirow{2}{*}{ Transportation } & $0.640 * * *$ & $0.507 * * *$ & $1.419 * * *$ & $0.770 * * *$ \\
\hline & $(0.0743)$ & $(0.0874)$ & $(0.154)$ & $(0.136)$ \\
\hline \multirow[t]{2}{*}{ Treasury } & $-0.105^{*}$ & $9.24 \mathrm{e}-05$ & $-0.284 * *$ & -0.00775 \\
\hline & $(0.0585)$ & $(0.0652)$ & $(0.121)$ & $(0.102)$ \\
\hline \multirow[t]{2}{*}{ Veterans Affairs } & $-1.067 * * *$ & $-0.705 * * *$ & $-1.951 * * *$ & $-1.025 * * *$ \\
\hline & $(0.0633)$ & $(0.0721)$ & $(0.124)$ & $(0.107)$ \\
\hline \multirow[t]{2}{*}{1991} & $-0.176 * * *$ & -0.0649 & $-0.193 * * *$ & $-0.824 * * *$ \\
\hline & $(0.0420)$ & $(0.0499)$ & $(0.0640)$ & $(0.0628)$ \\
\hline \multirow[t]{2}{*}{1992} & $-0.421 * * *$ & $-0.306 * * *$ & $-1.103 * * *$ & $-1.677 * * *$ \\
\hline & $(0.0433)$ & $(0.0512)$ & $(0.0641)$ & $(0.0624)$ \\
\hline \multirow[t]{2}{*}{1993} & $-0.394 * * *$ & $-0.263 * * *$ & $-1.899 * * *$ & $-2.386 * * *$ \\
\hline & $(0.0434)$ & $(0.0509)$ & $(0.0646)$ & $(0.0627)$ \\
\hline \multirow[t]{2}{*}{1994} & $-0.485 * * *$ & $-0.373 * * *$ & $-2.197 * * *$ & $-2.711 * * *$ \\
\hline & $(0.0445)$ & $(0.0520)$ & $(0.0652)$ & $(0.0629)$ \\
\hline \multirow[t]{2}{*}{1995} & $-0.419 * * *$ & $-0.265 * * *$ & $-2.525 * * *$ & $-3.050 * * *$ \\
\hline & $(0.0448)$ & $(0.0511)$ & $(0.0661)$ & $(0.0631)$ \\
\hline \multirow[t]{2}{*}{1996} & $-0.407 * * *$ & $-0.284 * * *$ & $-1.868 * * *$ & $-2.438 * * *$ \\
\hline & $(0.0464)$ & $(0.0530)$ & $(0.0681)$ & $(0.0647)$ \\
\hline \multirow[t]{2}{*}{1997} & $-0.351 * * *$ & $-0.235 * * *$ & $-2.046^{* * *}$ & $-2.678 * * *$ \\
\hline & $(0.0469)$ & $(0.0533)$ & $(0.0692)$ & $(0.0654)$ \\
\hline \multirow[t]{2}{*}{1998} & $-0.185^{* * *}$ & -0.0777 & $-1.041 * * *$ & $-1.680 * * *$ \\
\hline & $(0.0478)$ & $(0.0540)$ & $(0.0717)$ & $(0.0675)$ \\
\hline \multirow[t]{2}{*}{1999} & $-0.194 * * *$ & $-0.111 *$ & $0.208 * * *$ & $-0.516^{* * * *}$ \\
\hline & $(0.0533)$ & $(0.0603)$ & $(0.0785)$ & $(0.0740)$ \\
\hline \multirow[t]{2}{*}{2000} & -0.0328 & 0.0586 & $-0.408 * * *$ & $-1.186 * * *$ \\
\hline & $(0.0541)$ & $(0.0616)$ & $(0.0812)$ & $(0.0771)$ \\
\hline \multirow[t]{2}{*}{2001} & 0.0761 & $0.177 * * *$ & $0.491 * * *$ & $-0.266 * * *$ \\
\hline & $(0.0548)$ & $(0.0623)$ & $(0.0833)$ & $(0.0789)$ \\
\hline \multirow[t]{2}{*}{2002} & 0.0915 & 0.0977 & -0.0899 & $-0.947 * * *$ \\
\hline & $(0.0579)$ & $(0.0670)$ & $(0.0882)$ & $(0.0832)$ \\
\hline
\end{tabular}




$\begin{array}{lllll}1989 & -0.0175 & -0.467 * * * & \\ & (0.0411) & (0.0635) & \\ 1990 & -0.119 * * * & & 0.716^{* * *} & \\ & (0.0415) & & (0.0636) & \\ \text { Constant } & -0.465^{* *} & -0.940^{* * *} & -2.235^{* * *} & 12.64 * * * \\ & (0.213) & (0.268) & (0.414) & (0.414) \\ & & & & \\ \text { Observations } & 120,598 & 84,731 & 120,598 & 84,731 \\ \text { Number of ssn } & 17,083 & 13,650 & 17,083 & 13,650\end{array}$


Table 4. Findings by Agency and Year of Federal Service

Agency
Air Force
Agriculture
Army
Commerce
Defense
Justice
Energy
General Services Adminis
Housing \& Urban Developm
Interior
National Aeronautics and
$\quad$ Space Administration
Navy
Social Security Adminstration
Transportation
Treasury
Veterans Affairs
Other Agencies
Year of Federal Service
First
Second
Third
Fourth
Fifth
Sixth
Seventh
Eighth
Ninth

\begin{tabular}{|c|c|c|c|}
\hline $\begin{array}{c}\text { Odds-Ratio } \\
\text { for Promotion }\end{array}$ & $\begin{array}{c}\text { Raise } \\
\text { Coefficient }\end{array}$ & $\begin{array}{c}\text { Percent Rated } \\
\text { Outstanding }\end{array}$ & $\begin{array}{c}\text { Sample } \\
\text { Size }\end{array}$ \\
\hline $1.23 * * *$ & -0.074 & 41.4 & 11567 \\
\hline $1.34 * * *$ & 0.164 & 11.1 & 8176 \\
\hline $1.15 * * *$ & $0.136^{*}$ & 60.0 & 19557 \\
\hline $1.23 *$ & $0.373 *$ & 39.0 & 1898 \\
\hline $1.35 * * *$ & $0.191 *$ & 35.6 & 6861 \\
\hline 1.11 & 0.028 & 38.8 & 6295 \\
\hline 1.27 & $0.581 *$ & 29.5 & 1245 \\
\hline 1.21 & 0.173 & 34.8 & 1043 \\
\hline $1.34 * * *$ & 0.357 & 43.1 & 1335 \\
\hline $1.32 * * *$ & 0.192 & 17.1 & 3264 \\
\hline $1.55^{* * *}$ & 0.303 & 35.9 & 1425 \\
\hline $1.21 * * *$ & $0.125^{*}$ & 35.5 & 15238 \\
\hline $2.10 * * *$ & $0.387 *$ & 18.1 & 1458 \\
\hline 1.11 & -0.175 & 16.4 & 3746 \\
\hline $1.25 * * *$ & $0.203 * *$ & 19.8 & 13122 \\
\hline $1.30 * * *$ & $0.181 * * *$ & 24.3 & 11349 \\
\hline $1.29 * * *$ & $0.268 * * *$ & 28.4 & 13019 \\
\hline 1.09 & 0.192 & 16.0 & 1286 \\
\hline $1.19 * * *$ & 0.200 & 18.9 & 2955 \\
\hline $1.11 *$ & -0.047 & 23.3 & 3800 \\
\hline $1.22 * * *$ & $0.333^{*}$ & 26.3 & 4353 \\
\hline $1.26 * * *$ & $0.384 * *$ & 28.1 & 4762 \\
\hline $1.26^{* * * *}$ & $0.337 * *$ & 29.2 & 5020 \\
\hline $1.22 * * *$ & $0.302 * *$ & 30.3 & 5233 \\
\hline $1.11 *$ & 0.164 & 32.1 & 5374 \\
\hline $1.23 * * *$ & $0.341 * * *$ & 33.6 & 5554 \\
\hline
\end{tabular}




$\begin{array}{lllll}\text { Tenth } & 1.24^{* * *} & 0.294^{* * *} & 34.6 & 5611 \\ \text { Eleventh } & 1.24^{* * *} & 0.203^{* *} & 35.0 & 5595 \\ \text { Twelfth } & 1.15^{*} & 0.118 & 35.5 & 5528 \\ \text { Thirteenth } & 1.21^{* *} & 0.106 & 36.2 & 5397 \\ \text { Fourteenth } & 1.22^{* *} & 0.237^{* *} & 37.0 & 5362 \\ \text { Fifteenth } & 1.29^{* * *} & 0.226^{* *} & 37.2 & 5146 \\ \text { Sixteenth } & 1.20^{* *} & 0.174^{*} & 36.6 & 4969 \\ \text { Seventeenth } & 1.15^{*} & 0.191^{* *} & 36.9 & 4856 \\ \text { Eighteenth } & 1.35^{* * *} & 0.132 & 36.3 & 4612 \\ \text { Nineteenth } & 1.17^{*} & 0.266^{* *} & 36.9 & 4395 \\ \text { Twentieth } & 1.21^{*} & 0.184^{*} & 37.3 & 4158 \\ \text { Twenty-first } & 1.26^{* *} & 0.199^{* *} & 36.4 & 3963 \\ \text { Twenty-second } & 1.19^{*} & 0.166^{*} & 37.1 & 3737 \\ \text { Twenty-third } & 1.22^{*} & 0.078 & 37.3 & 3524 \\ \text { Twenty-fourth } & 1.43^{* * *} & 0.167 * & 36.2 & 3336 \\ \text { Twenty-fifth } & 1.37^{* *} & 0.200^{*} & 37.0 & 2966 \\ \text { Twenty-sixth } & 1.49^{* * *} & 0.266^{* *} & 37.1 & 2681 \\ \text { Twenty-seventh } & 1.25^{*} & 0.195^{*} & 37.5 & 2296 \\ \text { Twenty-eighth } & 1.26 & 0.128 & 35.8 & 2096 \\ \text { Twenty-ninth } & 1.15 & 0.149 & 36.4 & 1772\end{array}$

